\title{
Penggunaan Technology Acceptance Model untuk Mengidentifikasi Faktor-faktor yang Berpengaruh dengan Penggunaan Sistem Informasi Pengelolaan Keuangan pada Pegawai di Perguruan Tinggi
}

\author{
Tri Yuniatin ${ }^{\mathrm{a}} *$ \\ ${ }^{a}$ Universitas Brawijaya, Malang, Jawa Timur, Indonesia
}

\section{INFORMASI ARTIKEL}

\section{Article history:}

Dikirim tanggal: 02 Mei 2019

Revisi pertama tanggal: 13 Juni 2019

Diterima tanggal: 30 April 2019

Tersedia online tanggal: 07 Agustus 2019

Keywords: financial management information system, technology acceptance model

\begin{abstract}
Financial Management Information System (SIPK) is one of the determinants on the success of a university especially in Universitas Brawijaya (UB). The existence of Government Regulation of the Republic of Indonesia Number 61 of 1999 about the Establishment of Higher Education Institutions (universities) as a Legal Entity has produced a shift in the internal management system of a university. Therefore, SIPK is needed which is expected to simplify and accelerate the working results of employees. This can help to realize UB's vision and mission. A good SIPK is accepted by users. There are several factors that influence the use of SIPK so that it is necessary to identify these factors using Technology Acceptance Model (TAM). By knowing the factors that influence or not in using SIPK, it can be used as an evaluation for further improvement of SIPK in UB.
\end{abstract}

\section{INTISARI}

Sistem Informasi Pengelolaan Keuangan (SIPK) merupakan salah satu penentu keberhasilan sebuah Perguruan Tinggi terutama di Universitas Brawijaya (UB). Adanya PP No. 61 Tahun 1999, yaitu Penetapan Perguruan Tinggi (PT) sebagai Badan Hukum, telah melahirkan pergeseran sistem manajemen internal PT. Sehingga diperlukan SIPK yang diharapkan mempermudah dan mempercepat hasil kerja pegawai sehingga dapat membantu mewujudkan visi dan misi UB. SIPK yang baik adalah SIPK yang dapat diterima oleh pengguna. Terdapat beberapa faktor yang berpengaruh terhadap penggunaan SIPK sehingga diperlukan untuk mengidentifikasi faktor-faktor tersebut dengan menggunakan Technology Acceptance Model (TAM). Dengan mengetahui faktor-faktor yang menjadi pengaruh maupun tidak dalam penggunaan SIPK dapat dijadikan sebagai evaluasi untuk lebih meningkatkan SIPK yang ada di UB.

2019 FIA UB. All rights reserved.

\section{Pendahuluan}

Perkembangan teknologi informasi menuntut masyarakat untuk bertindak efektif dan efisien dalam menghadapi persaingan yang begitu ketat. Kemajuan teknologi tersebut sangat berpengaruh disegala bidang terutama pada bidang pendidikan. Perubahan tersebut dilakukan agar sebuah organisasi menjadi lebih baik dalam menghadapi persaingan dan meningkatkan kinerjanya. Dengan adanya sistem yang baik maka pengelolaan sumberdaya informasi akan berjalan dengan

\footnotetext{
* Corresponding author. Tel.: +62-813-3318-0083; e-mail: ms_yuni@ub.ac.id
} 
optimal. Sistem informasi dapat dibentuk sesuai dengan kebutuhan organisasi. Untuk dapat menerapkan sistem informasi yang efektif dan efisien diperlukan perencanaan, pelaksanaan, pengaturan, dan evaluasi sesuai dengan keinginan dan nilai masing-masing organisasi (Sutabri, 2012). Oleh karena itu organisasi tidak dapat sekedar mengadaptasi setiap sistem yang ditawarkan tetapi harus mendapatkan sistem yang efektif dan efisien sesuai dengan keinginan dan tujuan dari organisasi tersebut.

Penggunaan sistem informasi dengan baik akan menentukan keberhasilan sebuah organisasi secara keseluruhan. Penerapan sistem informasi tersebut tidaklah mudah, banyak dari penelitian yang menunjukkan bahwa penyebab kegagalannya, yaitu lebih pada aspek keperilakuannya (behavioral) (Jogiyanto, 2008). Manusia berinteraksi menggunakan sistem teknologi informasi, interaksi tersebut dapat menimbulkan masalah keprilakuan. Beberapa manusia menolak penggunaan sistem teknologi informasi dikarenakan banyak faktor dan alasan. Supaya sistem teknologi informasi dapat diterima baik oleh penggunanya, maka perilaku menolak perlu diubah atau sistem tersebut dipersiapkan lebih baik dan memudahkan penggunanya. Mengubah perilaku tidak dapat dilakukan secara langsung, tetapi harus dilakukan melalui penyebab perilaku tersebut. Salah satu penyebab dari perilaku tersebut yaitu kepercayaan (belief) terhadap sistem informasi (Jogiyanto, 2008). Dengan demikian mengubah perilaku dapat dilakukan dengan mengubah kepercayaan dari individual menjadi kepercayaan yang positif untuk menerima sistem teknologi informasinya.

Universitas Brawijaya (UB) mengembangkan beberapa sistem informasi pengelolaan keuangan seperti Sistem Informasi Manajemen (SIM), Sistem Informasi Pelaporan (SIMPEL), Sistem Informasi Remunerasi, Sistem Informasi Rencana Kerja Anggaran (SIREKA), Sistem Informasi Keuangan-Realisasi Belanja (SIMKEU-RB), dan Daftar Isian Pelaksanaan Anggaran (DIPA). Penggunaan sistem informasi pengelolaan keuangan tersebut diharapkan dapat mempermudah dan mempercepat hasil kerja yang bertujuan untuk membantu mewujudkan visi dan misi bagi UB. Munculnya perkembangan sistem informasi pengelolaan yang ada di UB tersebut salah satunya berasal dari berbagai masalah yang terjadi pada pengguna. Berbagai macam respon yang nampak dari pemakaian SIPK sampai saat ini. Pengguna ada yang dengan mudah menerima penggunaan SIPK dan ada juga yang tidak dapat menerima penggunaan SIPK. Penerimaan terhadap SIPK dapat berdampak pada kemajuan UB. Untuk mengurangi dampak negatif dari penerimaan terhadap SIPK tersebut dan dapat menjadi pengembangan terhadap SIPK di UB maka digunakanlah Model Penerimaan Teknologi (Technology Acceptance Model) atau disingkat TAM.
TAM merupakan suatu model penerimaan sistem teknologi informasi yang akan digunakan oleh pengguna. TAM dikembangkan oleh Davis et al., (1989) berdasarkan Model Theory of Reasoned Action (TRA). Model TRA menjelaskan adanya reaksi dan persepsi pengguna Teknologi Informasi (TI) yang pada akhirnya akan mempengaruhi sikapnya dalam penerimaan terhadap teknologi tersebut. Tujuan utama TAM, yaitu memberikan penjelasan tentang penentuan penerimaan komputer secara umum, memberikan penjelasan tentang perilaku atau sikap pengguna dalam suatu populasi (Davis, et al., 1989).

Untuk mengidentifikasi faktor-faktor yang berpengaruh dengan penggunaan Sistem Informasi Pengelolaan Keuangan (SIPK) dalam penelitian ini, peneliti menggunakan variabel TAM, yaitu Persepsi Terhadap Kegunaan (Perceived Usefulness/ PU), Persepsi Terhadap Kemudahan Penggunaan (Perceived Ease of Usel PEOU), Sikap Terhadap Penggunaan (Attitude Toward Using/AT), Niat Perilaku untuk Menggunakan (Behavioral Intention to Usel BI), dan Pemakaian Sistem Secara Nyata (Actual System Usagel U). Dan tiga variabel eksternal, yaitu Usia (Age)/A, Pengalaman (Experiencel EX), dan Kerumitan (Complexity/ C).

Merujuk pada hal latar belakang diatas, rumusan masalah penelitian ini adalah faktor-faktor apa sajakah yang berpengaruh dengan penggunaan sistem informasi pengelolaan keuangan oleh pegawai di Universitas Brawijaya?. Adapun tujuan penelitian adalah untuk mengetahui dan menganalisis faktor-faktor yang berpengaruh dengan penggunaan sistem informasi pengelolaan keuangan pada pegawai di UB dengan TAM. Hasilnya akan digunakan sebagai pengembangan SIPK UB yang dapat meningkatkan kinerja bagi pegawai.

\section{Teori}

\subsection{Teori Penggunaan Sistem Teknologi Informasi}

Teori penggunaan sistem teknologi informasi yang dianggap sangat berpengaruh dan umumnya digunakan untuk menjelaskan penerimaan individual terhadap penggunaan sistem teknologi informasi adalah model penerimaan teknologi (Technology Acceptance Model) atau disingkat TAM. Model penerimaan teknologi (TAM) yang dikembangkan oleh Davis et al. (1989) berdasarkan (Theory of Reasoned Action) atau TRA oleh Ajzen \& Martin Fishbein (1975). Dalam TRA keputusan yang dilakukan oleh individu untuk menerima suatu teknologi sistem informasi merupakan tindakan sadar yang dapat dijelaskan dan dapat diprediksi oleh minat perilakunya.

Davis et al., (1989) mengembangan TAM yang digunakan untuk meneliti faktor-faktor determinan dari penggunaan sistem informasi oleh pengguna. Beberapa 
peneliti mencoba untuk mengembangkan TAM dengan menambahkan beberapa variabel eksternal yang menerangkan lebih lanjut dari persepsi terhadap kegunaan (perceived usefulness) dan persepsi terhadap kemudahan penggunaan (perceived ease of use). Perkembangan TAM sampai dengan Tahun 2003 oleh Lee et al., (2003) didalam Jogiyanto (2008:118) dapat dilihat pada gambar 1, yaitu sebagai berikut:

\subsection{Variabel External}

Gardner \& Amoroso (2004) mengembangkan TAM dengan menambah empat variabel eksternal dalam meneliti penerimaan pelanggan menggunakan teknologi internet. Empat variabel eksternal tersebut, yaitu jenis kelamin (gender), pengalaman (experience), kerumitan (complexity), dan kesukarelaan (voluntariness). Dalam penelitian Tarhini et al., (2014) menggunakan variabel prediktor tambahan, yaitu: usia dan pengalaman.

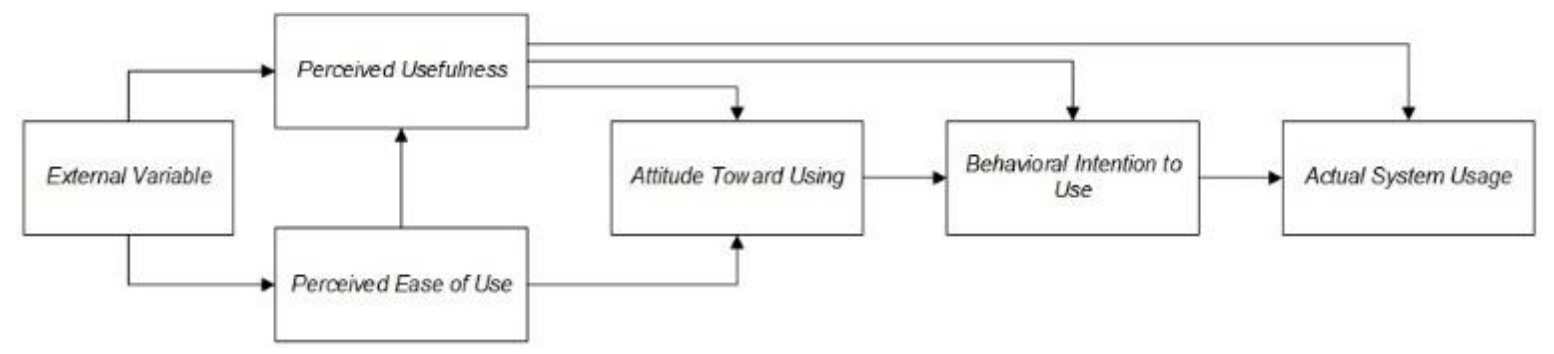

Gambar 1 Pengembangan TAM

Sumber: Jogiyanto, 2008

\subsection{Variabel Internal}

Persepsi terhadap kegunaan (perceived usefulness), yaitu sejauh mana seseorang yakin bahwa menggunakan sistem akan meningkatkan kinerja pekerjaannya. Dengan demikian jika seseorang merasa percaya bahwa sistem informasi berguna maka dia akan menggunakannya. Sebaliknya jika seseorang merasa percaya bahwa sistem informasi kurang berguna maka dia tidak akan menggunakannya.

Persepsi terhadap kemudahan penggunaan (perceived ease of use), yaitu sejauh mana seseorang percaya bahwa menggunakan suatu teknologi akan bebas dari usaha. Dengan demikian jika seseorang merasa percaya bahwa sistem informasi mudah digunakan maka dia akan menggunakannya. Sebaliknya jika seseorang merasa percaya bahwa sistem informasi tidak mudah digunakan maka dia tidak akan menggunakannya.

Sikap terhadap penggunaan (attitude toward using) didefinisikan oleh Davis et al., (1989) sebagai perasaan positif atau negatif dari seseorang jika harus melakukan perilaku yang akan ditentukan.

Niat perilaku untuk menggunakan (behavioral intention to use), yaitu keinginan (minat) seseorang untuk melakukan suatu perilaku tertentu. Seseorang akan melakukan suatu perilaku (behavior) jika mempunyai keinginan atau minat untuk melakukannya.

Pemakaian sistem secara nyata (actual system usage), yaitu tindakan yang dilakukan oleh seseorang dalam konteks penggunaan sistem teknologi informasi.
Berdasarkan beberapa penelitian terdahulu dan disesuaikan dengan kondisi pada tempat penelitian, peneliti menggunakan tiga variabel eksternal, yaitu umur (age), pengalaman (experience), dan kerumitan (complexity).

\subsection{Sistem Informasi Pengelolaan Keuangan}

Menurut Tata Sutabri (2012), sistem informasi keuangan merupakan sistem informasi yang memberikan informasi kepada orang atau kelompok baik dalam organisasi maupun di luar organisasi mengenai masalah keuangan. Berdasarkan pengertian sistem informasi pada bagian sebelumnya, maka sistem informasi pengelolaan keuangan yaitu sebuah sistem yang terkomputerisasi dalam mengumpulkan, menyimpan dan mengelola data serta menghasilkan informasi bagi pengguna dalam memenuhi kebutuhan pada bidang keuangan yang digunakan untuk mencapai tujuan tertentu.

Adanya PP No. 61 Tahun 1999 tentang Penetapan Perguruan Tinggi (PT) sebagai Badan Hukum, telah melahirkan pergeseran sistem manajemen internal PT. Pengambilan berbagai kebijaksanaan pendidikan tinggi yang tadinya relatif terpusat di Ditjen Dikti, berikutnya secara bertahap akan diberikan kepada masing-masing PT. Sehingga memberikan keleluasaan yang lebih tinggi bagi pimpinan PT untuk mengatur pemanfaatan sumber daya yang dimiliki sesuai dengan visi dan misi PT yang bersangkutan. Konsekuensi tersebut menimbulkan perlunya sistem yang mampu untuk mensinergikan segala sumber daya yang ada atau sentralisasi pada tingkat internal PT untuk mengoptimalisasi pemanfaatan sumber daya. 
Dilingkungan PT, pengelola keuangan yang bertugas sebagai pengelola sistem informasi pengelolaan keuangan melakukan kewajibannya berdasarkan surat pengajuan dari PT dan disahkan oleh Kementerian Riset Teknologi dan Pendidikan Tinggi (Kemenristek Dikti). Beberapa PT menggunakan aplikasi yang tersentralisasi yang bertujuan untuk membantu dalam pelaksanaannya. Penggunaan sistem informasi pengelolaan keuangan tersebut diharapkan mempermudah dan mempercepat hasil kerja pegawai sehingga dapat membantu mewujudkan visi dan misi bagi masing-masing PT.

\section{Metode Penelitian}

Penelitian ini menggunakan metode kuantitatif dengan pendekatan deskriptif. Lokasi penelitian dilingkungan UB yang terdiri dari 1 Biro Keuangan, 15 Fakultas, dan 2 Program Pendidikan. Jumlah populasi sebanyak 157, yaitu sesuai dengan pejabat perbendaharaan/ pengelola keuangan Tahun Anggaran 2018. Teknik pengambilan sampel yang digunakan adalah pusposive sampling dengan jumlah sampel sebanyak 105 orang terdiri dari monitoring, bendahara penerimaan, bendahara pengeluaran, petugas pengelola anggaran belanja pegawai (PPABP), simak dan persediaan. Teknik pengumpulan data menggunakan metode survei dengan kuesioner dan wawancara. Skala pengukuran menggunakan skala likert.

Teknik analisis data menggunakan WarpPLS merupakan bagian dari analisis multivariat yang disebut analisis peubah ganda. Tahapan analisis WarpPLS, yaitu: merancang model struktural (inner model), merancang model pengukuran (outer model), mengkonstruksi diagram jalur, konversi diagram jalur ke sistem persamaan, estimasi outer model dan inner model, evaluasi goodness of fit, dan pengujian hipotesis.

\section{Hasil Penelitian dan Pembahasan}

Hasil dari penyebaran kuesioner yang dilakukan dengan menggunakan Google Formulir sejumlah 100 responden, terdiri dari: monitoring total 17 responden dari 18 responden, bendahara penerimaan total 19 responden dari 19 responden, bendahara pengeluaran total 19 responden dari 20 responden, PPABP total 22 responden dari 22 responden, simak dan persediaan total 23 responden dari 26 responden.

\subsection{Analisis Data Penelitian}

Dari pengguna SIPK di UB dapat diketahui banyak pengguna laki-laki dari pada perempuan. Pengguna SIPK rata-rata berusia antara 36 - 45 tahun. Pengguna SIPK rata-rata berpendidikan terakhir S1. Pengguna SIPK paling banyak berada pada unit kerja Biro Keuangan. Pengguna rata-rata banyak yang telah menggunakan SIPK lebih dari satu tahun.
Uji Validitas dan Reliabilitas instrumen penelitian, yaitu: variabel Experience (EX), Complexity (C), Perceived usefulness (PU), Perceived ease of use (PEOU), Attitude Toward Using (AT), dan Behavioral Intention to Use (BI) adalah valid dan reliabel yang artinya indikator dari tiap-tiap variabel tersebut sudah sesuai. Untuk Actual System Usage (U) menunjukkan hasil tidak valid dan tidak reliabel dapat diartikan bahwa indikator dari variabel tersebut perlu penjelasan lebih detil.

\subsection{Hasil Analisis Data SEM}

Hasil uji pada nilai Goodness of Fit Model dapat dilihat pada tabel berikut ini:

Tabel 1 Nilai Goodness of Fit Model

\begin{tabular}{|c|c|c|c|}
\hline No. & $\begin{array}{l}\text { Model fit and } \\
\text { quality indices }\end{array}$ & Kriteria Fit & $\begin{array}{l}\text { Hasil } \\
\text { Uji }\end{array}$ \\
\hline 1 & $\begin{array}{l}\text { Average Path } \\
\text { Coefficient (APC) }\end{array}$ & $\begin{array}{l}p \text {-value }< \\
0,05\end{array}$ & $\begin{array}{l}p \text {-value } \\
=0,001\end{array}$ \\
\hline 2 & $\begin{array}{l}\text { Average } R- \\
\text { Squared (ARS) }\end{array}$ & $\begin{array}{l}p \text {-value }< \\
0,05\end{array}$ & $\begin{array}{l}p \text {-value } \\
<0,001\end{array}$ \\
\hline 3 & $\begin{array}{l}\text { Average adjusted } \\
R \text {-squared }\end{array}$ & $\begin{array}{l}p \text {-value }< \\
0,05\end{array}$ & $\begin{array}{l}p \text {-value } \\
<0,001\end{array}$ \\
\hline 4 & $\begin{array}{l}\text { Average block VIF } \\
(A V I F)\end{array}$ & $\begin{array}{l}\text { Diterima } \\
\text { jika } \leq 5\end{array}$ & 1,637 \\
\hline 5 & $\begin{array}{l}\text { Average full } \\
\text { collinearity VIF }\end{array}$ & $\begin{array}{l}\text { Diterima } \\
\text { jika } \leq 5\end{array}$ & 2,201 \\
\hline 6 & $\begin{array}{l}\text { Tenenhaus GoF } \\
(\text { GoF })\end{array}$ & $\begin{array}{l}\text { Kecil } \geq 0,1 \\
\text { Sedang } \geq \\
0,25 \\
\text { Besar } \geq \\
0,36\end{array}$ & 0.578 \\
\hline 7 & $\begin{array}{l}\text { Symphson's } \\
\text { paradox ratio }\end{array}$ & $\begin{array}{l}\text { Diterima } \\
\text { jika } \geq 0,7\end{array}$ & 0,867 \\
\hline 8 & $\begin{array}{l}R \text { squared } \\
\text { contribution ratio }\end{array}$ & $\begin{array}{l}\text { Diterima } \\
\text { jika } \geq 0,9\end{array}$ & 0,993 \\
\hline 9 & $\begin{array}{l}\text { Statistical } \\
\text { suppression ratio }\end{array}$ & $\begin{array}{l}\text { Diterima } \\
\text { jika } \geq 0,7\end{array}$ & 0,933 \\
\hline 10 & $\begin{array}{l}\text { Nonlinier } \\
\text { bivariate causality } \\
\text { direction ratio } \\
(N L B C D R)\end{array}$ & $\begin{array}{l}\text { Diterima } \\
\text { jika } \geq 0,7\end{array}$ & 1,000 \\
\hline
\end{tabular}

Sumber: Hasil analisis, 2019

Dari hasil uji pada Goodness of Fit Model banyak indikator yang telah memenuhi, sehingga dapat diartikan bahwa model pengujian tersebut sudah tepat untuk digunakan dalam penelitian ini.

Hasil outer model pada analisis WarpPLS menunjukkan bahwa variabel Experience (EX), Complexity (C), Perceived Usefulness (PU), Perceived Ease of Use (PEOU), Attitude Toward Using (AT), 
Behavioral Intention to Use (BI) dan Actual System Usage (U) adalah signifikan. Artinya bahwa indikator pada tiap-tiap variabel tersebut berpengaruh. Hasil analisis dapat dilihat pada tabel berikut:

Tabel 2 Hasil Analisis WarpPLS

Pengaruh Langsung

\begin{tabular}{|c|c|c|c|c|}
\hline $\mathrm{H}$ & Hubungan & Koefisien & P-value & Ket \\
\hline H1 & $\begin{array}{l}\text { Age (A) terhadap } \\
\text { Perceived } \\
\text { Usefulness (PU) }\end{array}$ & $0.061^{\mathrm{ns}}$ & 0.268 & $\begin{array}{c}\text { Tidak } \\
\text { Signifikan }\end{array}$ \\
\hline $\mathrm{H} 2$ & $\begin{array}{l}\text { Age (A) terhadap } \\
\text { Perceived Ease of } \\
\text { Use (PEOU) }\end{array}$ & $0.050^{\mathrm{ns}}$ & 0.307 & $\begin{array}{c}\text { Tidak } \\
\text { Signifikan }\end{array}$ \\
\hline $\mathrm{H} 3$ & $\begin{array}{l}\text { Age (A) terhadap } \\
\text { Actual System } \\
\text { Usage }(\mathrm{U})\end{array}$ & $0.126^{\mathrm{ns}}$ & 0.098 & $\begin{array}{c}\text { Tidak } \\
\text { Signifikan }\end{array}$ \\
\hline $\mathrm{H} 4$ & $\begin{array}{l}\text { Experience }(\mathrm{EX}) \\
\text { terhadap Perceived } \\
\text { Usefulness }(\mathrm{PU})\end{array}$ & $0.222 *$ & 0.010 & Signifikan \\
\hline H5 & $\begin{array}{l}\text { Experience (EX) } \\
\text { terhadap Perceived } \\
\text { Ease of Use } \\
\text { (PEOU) }\end{array}$ & $0.639 *$ & $<0.001$ & Signifikan \\
\hline H6 & $\begin{array}{l}\text { Experience (EX) } \\
\text { terhadap Behavioral } \\
\text { Intention of Use } \\
\text { (BI) }\end{array}$ & $0.363^{*}$ & $<0.001$ & Signifikan \\
\hline H7 & $\begin{array}{l}\text { Complexity }(\mathrm{C}) \\
\text { terhadap Perceived } \\
\text { Usefulness }(\mathrm{PU})\end{array}$ & $0.210^{*}$ & 0.014 & Signifikan \\
\hline $\mathrm{H} 8$ & $\begin{array}{l}\text { Complexity (C) } \\
\text { terhadap Actual } \\
\text { System Usage }(\mathrm{U})\end{array}$ & $0.103^{\text {ns }}$ & 0.147 & $\begin{array}{c}\text { Tidak } \\
\text { Signifikan }\end{array}$ \\
\hline H9 & $\begin{array}{l}\text { Perceived } \\
\text { Usefulness (PU) } \\
\text { terhadap Attitude } \\
\text { Toward Using (AT) }\end{array}$ & $0.319 *$ & $<0.001$ & Signifikan \\
\hline H10 & $\begin{array}{l}\text { Perceived } \\
\text { Usefulness (PU) } \\
\text { terhadap Behavioral } \\
\text { Intention to Use } \\
\text { (BI) }\end{array}$ & $0.048^{\text {ns }}$ & 0.315 & $\begin{array}{c}\text { Tidak } \\
\text { Signifikan }\end{array}$ \\
\hline H11 & $\begin{array}{l}\text { Perceived } \\
\text { Usefulness (PU) } \\
\text { terhadap Actual } \\
\text { System Usage (U) }\end{array}$ & $0.134^{\mathrm{ns}}$ & 0.083 & $\begin{array}{c}\text { Tidak } \\
\text { Signifikan }\end{array}$ \\
\hline H12 & $\begin{array}{l}\text { Perceived Ease of } \\
\text { Use (PEOU) } \\
\text { terhadap Perceived } \\
\text { Usefulness (PU) }\end{array}$ & $0.433^{*}$ & $<0.001$ & Signifikan \\
\hline H13 & $\begin{array}{l}\text { Perceived Ease of } \\
\text { Use (PEOU) } \\
\text { terhadap Attitude } \\
\text { Toward Using (AT) }\end{array}$ & $0.534 *$ & $<0.001$ & Signifikan \\
\hline H14 & $\begin{array}{l}\text { Attitude Toward } \\
\text { Using (AT) } \\
\text { terhadap Behavioral } \\
\text { Intention to Use } \\
\text { (BI) }\end{array}$ & $0.425^{*}$ & $<0.001$ & Signifikan \\
\hline H15 & $\begin{array}{l}\text { Behavioral } \\
\text { Intention to Use } \\
\text { (BI) terhadap Actual } \\
\text { System Usage (U) }\end{array}$ & $0.301 *$ & $<0.001$ & Signifikan \\
\hline
\end{tabular}

Sumber: Hasil analisis, 2019
Hasil (inner model) pengujian model struktural pengaruh langsung dapat dijelaskan sebagai berikut:

a) Usia pengguna (age) tidak mempengaruhi terhadap manfaat SIPK yang dirasakan oleh pengguna (perceived usefulness);

b) Usia pengguna (age) tidak mempengaruhi terhadap kemudahan yang dirasakan oleh pengguna SIPK (perceived ease of use);

c) Usia pengguna (age) tidak mempengaruhi terhadap penggunaan SIPK (actual system usage);

d) Semakin banyak pengalaman (experience) yang dimiliki pengguna SIPK maka semakin besar manfaat SIPK yang dirasakan oleh pengguna (perceived usefulness);

e) Semakin banyak pengalaman (experience) yang dimiliki pengguna SIPK maka semakin mudah yang dirasakan oleh pengguna dalam menggunakan SIPK (perceived ease of use);

f) Semakin banyak pengalaman (experience) yang dimiliki pengguna SIPK maka semakin besar niat yang dimiliki pengguna untuk menggunakan SIPK (behavioral intention to use);

g) Semakin tinggi kesulitan (complexity) dalam menggunakan SIPK maka pengguna akan merasa bahwa SIPK tersebut kurang bermanfaat (perceived usefulness);

h) Kesulitan (complexity) dalam penggunaan SIPK tidak mempengaruhi terhadap penggunaan SIPK (actual system usage);

i) Semakin besar manfaat SIPK yang dirasakan oleh pengguna (perceived usefulness) maka pengguna akan bersikap positif untuk menggunakan SIPK (attitude toward using);

j) Manfaat SIPK bagi pengguna (perceived usefulness) tidak mempengaruhi terhadap niat pengguna untuk menggunakan SIPK (behavioral intention to use);

k) Manfaat SIPK bagi pengguna (perceived usefulness) tidak mempengaruhi terhadap penggunaan SIPK (actual system usage);

1) Semakin mudah yang dirasakan oleh pengguna dalam menggunakan SIPK (perceived ease of use) maka semakin besar manfaat yang dirasakannya (perceived usefulness);

m) Semakin mudah yang dirasakan oleh pengguna dalam menggunakan SIPK (perceived ease of use) maka pengguna akan bersikap positif untuk menggunakan SIPK (attitude toward using);

n) Semakin baik sikap yang dimiliki pengguna untuk menggunakan SIPK (attitude toward using) maka semakin besar niat yang dimiliki pengguna untuk menggunakan SIPK (behavioral intention to use); dan

o) Semakin besar niat pengguna untuk menggunakan SIPK (behavioral intention to use) maka semakin sering pengguna menggunakan SIPK (actual system usage). 


\subsection{Temuan Penelitian}

Perbedaan TAM dengan hasil penelitian dapat dilihat pada gambar 2 dan 3 berikut ini: oleh pengguna yang merasa mudah dalam menggunakan teknologi, pengguna yang merasa bahwa SIPK itu bermanfaat, pengguna yang bersikap menerima terhadap teknologi, pengguna yang mempunyai niat untuk

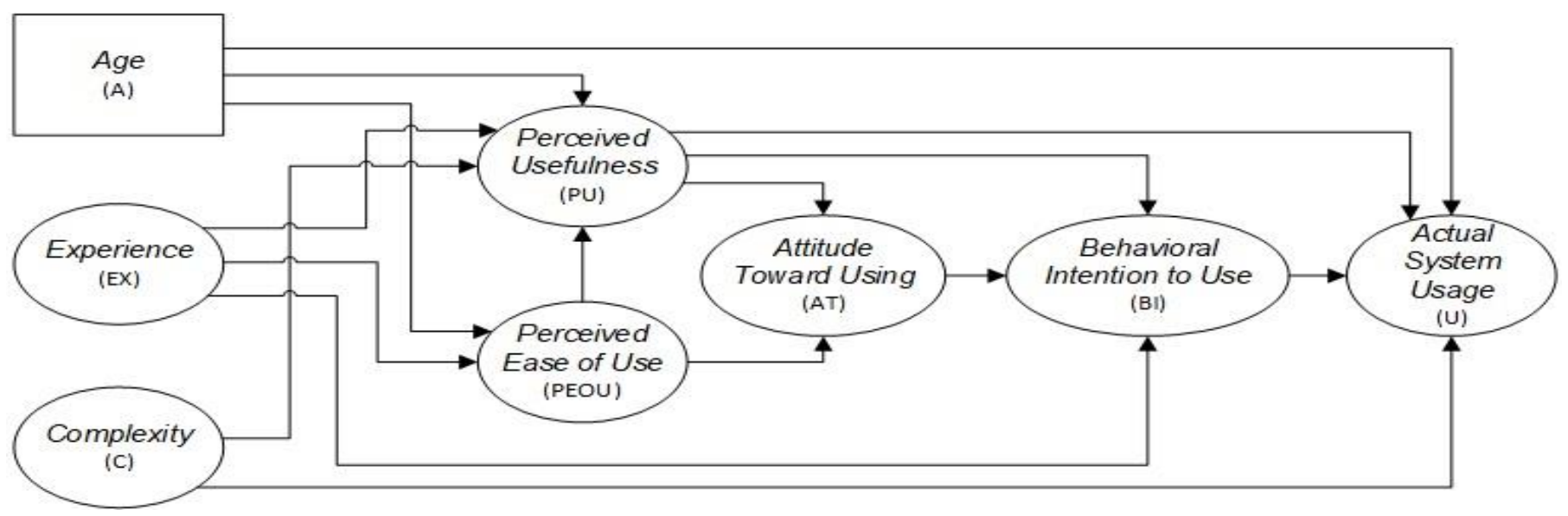

Gambar 2 Model TAM

Sumber: Hasil analisis, 2019

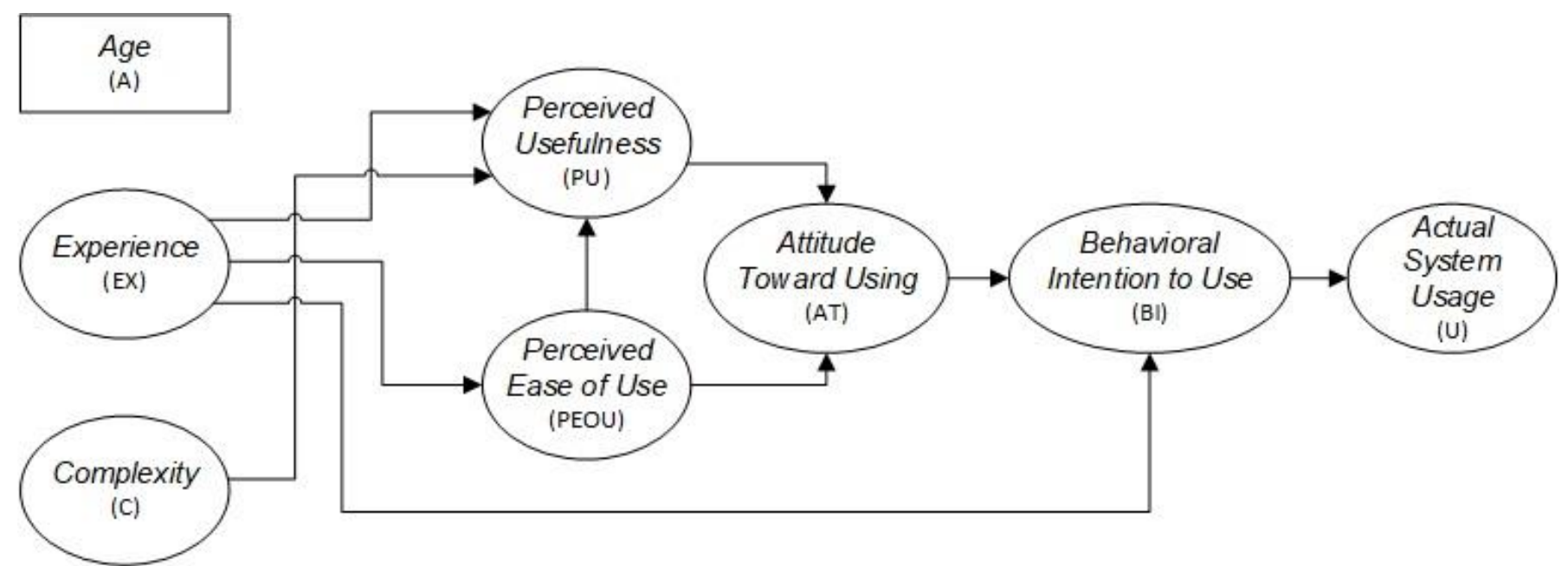

Gambar 3 Hasil Penelitian

Sumber: Hasil analisis, 2019

Dari gambar 2 dan gambar 3 dapat dilihat perbedaan model TAM dengan hasil penelitian. Hasil penelitian menunjukkan bahwa Age (A) tidak mempengaruhi Perceived Usefulness (PU), Perceived Ease of Use (PEOU), dan Actual System Usage (U). Complexity (C) tidak mempengaruhi Actual System Usage (U). Perceived Usefulness (PU) tidak mempengaruhi Behavioral Intention to Use (BI) dan Actual System Usage (U).

\section{Kesimpulan}

Hasil dari penelitian yang dilakukan untuk mengidentifikasi faktor-faktor yang berpengaruh dengan penggunaan SIPK pada pegawai di UB dengan menggunakan TAM terdapat persamaan dan beberapa perbedaan dari penelitian-penelitian terdahulu. Banyak faktor yang mempengaruhi penggunaan sistem informasi pengelolaan keuangan di UB, yaitu SIPK di UB diterima menggunakan teknologi dan pengguna yang berpengalaman dalam menggunakan teknologi.

Selain itu juga terdapat beberapa faktor yang tidak mempengaruhi penggunaan SIPK di UB, yaitu karena pengguna SIPK di UB rata-rata dalam usia produktif yang mana pengguna dapat menerima dan menggunakan teknologi lebih baik sehingga usia tidak mempengaruhi dalam penggunaan sistem. Meskipun banyak pengguna yang tidak merasa kesulitan ada beberapa dari pengguna SIPK yang merasakan kesulitan dalam penggunaannya tetapi mereka tetap menggunakan SIPK karena keharusan dalam menggunakannya.

Dengan diketahuinya faktor-faktor tersebut dapat dilakukan evaluasi untuk hasil yang lebih maksimal bagi pengguna. Agar SIPK dapat diterima oleh pengguna maka dilakukan peningkatan efektifitas penggunaan SIPK dengan melakukan pelatihan untuk pengguna SIPK 
karena pengguna yang berpengalaman lebih merasa mudah dan cepat dalam menggunakan SIPK juga meminimalkan kesalahan-kesalahan yang terjadi. Bagi unit pengembang SIPK di UB, dapat dijadikan evaluasi untuk lebih mengoptimalkan fungsi SIPK dengan memperbaiki dan mengembangkan SIPK sesuai dengan kebutuhan pengguna juga kebutuhan dimasa yang akan datang. Dengan begitu akan menumbuhkan keinginan pengguna untuk menggunakan SIPK yang hasilnya juga berpengaruh terhadap kinerja pegawai. Sedangkan bagi perguruan tinggi lain, dapat memberikan masukan bahwa untuk menerapkan SIPK dengan baik harus memperhatikan faktor-faktor yang mempengaruhi terhadap penggunaan SIPK.

\section{Daftar Pustaka}

Ajzen, I., \& Fishbein, M. (1980). Understanding attitudes and Predicting Social Behavior. Englewood Cliffs, N.J.: Prentice-Hall.

Davis, F. D., Bagozzi, R. P., \& Warshaw, P. R. (1989). User Acceptance of Computer Technology: A Comparison of Two Theoretical. Management Science, Vol. 35(8), pp.982-1003.

Gardner, C. \& Amoroso, D. L. (2004). Development of An Instrument to Measure The Acceptance of Internet Technology by Consumers. Proceedings of the 37th Hawaii International Conference on System Sciences - 2004, pp.1-10.

Jogiyanto, H. M. (2008). Sistem Informasi Keperilakuan $(E d$.). Yogyakarta: Andi Offset.

Peraturan Pemerintah Nomor 61 Tahun 1999 tentang Penetapan Perguruan Tinggi Negeri sebagai Badan Hukum.

Sutabri, T. (2012). Konsep Sistem Informasi. Yogyakarta: Andi.

Tarhini, A., Hone, K., \& Liu, X. (2014). Measuring The Moderating Effect of Gender and Age on ELearning Acceptance in England: A Structural Equation Modeling Approach for an Extended Technology Acceptance Model. Journal of Educational Computing Research, Vol. 51(2), pp.163-184. 